\title{
A Research Oriented Framework For The Development Of Marketing Strategies In The Turkish Construction Sector
}

\author{
M. Yaman ÖZTEK, Galatasaray University
}

Özgür ÇENGEL, Istanbul Commerce University

ABSTRACT In the Turkish Business Environment, construction sector plays a crucial role in the context of overall economic growth and sustainability. However, there have not been effective marketing strategies being implemented in order to enhance the profitability of the sector. This had occurred partly due to the fact that demand had been above the level of supply in the past. In contrast, nowadays fierce competition enforces that many construction projects are being promoted, thereby increasing the level of supply compared to the level of demand unlike what has happened in the past. As a result, genuine marketing strategies need to be emerged in order for construction companies to stay alive in this sector. With a sample size of 152, this paper aims to research the economic growth in terms of Turkish economy and construction sector. Besides, construction types, the biggest markets of construction companies, marketing/management strategies, and problems associated with the sector have been researched and debated with a specific focus on e-marketing/management approaches that have recently been revealed.

Keywords: Construction sector, Competition, E- marketing/management, Construction markets

\section{Türk İnşaat Sektöründe Pazarlama Stratejilerinin Gelişmesine Yönelik Araştirma Odakli Bir Çerçeve}

ÖZET Türk işletme çevrelerinde, inşaat sektörü genel ekonomik büyüme ve sürdürülebilirlik açısından önemli bir rol oynamaktadır. Fakat, sektörün karlılı̆̆ını güçlendirmek açısından etkin pazarlama stratejileri uygulanmamıştır. Bu kısmen geçmişte talebin arz seviyelerinden fazla olduğundan kaynaklanmıştır. Bugünlerde tam tersine, günümüzde yoğun rekabet yeni inşaat projelerinin tanıtılmasını zorunlu kılmaktadır. Bu yüzden, geçmişte olanın aksine, arz seviyeleri talep seviyelerine kıyasla artmaktadır. Sonuç olarak, inşaat firmalarının bu sektörde ayakta kalabilmeleri için özgün pazarlama stratejileri geliştirilmelidir. Bu makale 152 örneklem ile Türk ekonomisi ve inşaat sektörü açısından ekonomik büyümeyi araştırmaktadır. Bunun yanı sıra, inşaat türleri, inşaat firmalarının en büyük pazarları, pazarlamalyönetim stratejileri ve sektörün problemleri, son zamanlarda gündeme getirilen e-pazarlama/yönetim odaklı olarak araştırılmış ve tartışılmıştır.

Anahtar Kelimeler: İnşaat sektörü, rekabet, E-pazarlama/yönetim; İnşaat pazarları 


\section{Introduction}

Construction business had always been one of the major locomotive sectors in the Turkish Business Environment that brought prosperity and wealth to the overall Turkish Business. This occurs due to the fact that the geographical standing of the country is highly favorable and in terms of supply and demand ratios, there still is a great potential for growth considering new construction facilities and activities. Istanbul, in this sense, is positioned differently in a sense that new attraction facilities are being run in the aspect of building new bridges, new highways, easing up the transportation problems and issues and so forth. However, this paper discusses that more marketing attempt should be inserted as an attempt to promote the industry in the emerging and global markets.

\section{Turkish Economy and Major Economic Indicators}

Based on many research depicted from various resources in regards to the 4th Quarter of 2013, there is a slowing process in the Turkish economy and thus global financial institutions are perceiving the economy as somewhat unstable and fragile. However, Turkish Lira is losing its value and thus the purchasing power is highly diminished in return. The global capital that is in Turkey has decided to leave the country to some extent. As a result private spending and business investments are on the decrease. There is more focus on the savings side and the decrease in the consumption levels can be explained in there terms: High inflation, low credit usage, slowed down employment rates. (PWC Financial Report, 2013)

\section{Literature Review on the Major Determinants That Affect the Construction Sector in Turkey}

There are several indicators that affect the marketing strategies of construction business in Turkey. These are enlisted as office market (commercial), retail market, and industry and logistics market.

In terms of office market, 2013 was declared as highly favorable. User demand has dramatically increased and the rents have increased in this sense. However, the product offering is limited in this sense and new rent areas have been established. In this globe, the demand to the office market derives from foreign companies that aim to grow in the Turkish market. These sectors are namely the banking, insurance, consumer, and legal sectors. However, major metropolitan areas are becoming highly profitable as well. The level of investment opportunities to such areas are increasing and besides the attention to Ankara and İzmir is on the rise.

On the retail market side, supply and demand levels have been favorable and consumption expenditures have been on the rise. There has been an increase in the number of international brands who cooperated with local chains. More stores have been opened and 
investors have shifted more towards entertainment and lodging sectors as a means of alternative sectors. However, it is debated that as there occurs severe limitations to credit card usage, the effects to the retail sector may be negative. On the other side, if foreign currency rates go up, then it may be said that retail sector may be affected in a negative sense as the cost of rent may possibly go up.

In the industry and logistics market, it can be said that the Turkish economy has improved in a great sense and especially manufacturing and textile industries have cited great industrial success in this globe. It is seen that real estate business has also grown tremendously as depicted. In terms of logistics, transportation, delivery, and warehousing facilities have emerged and renting process in such fields have brought good profits to the sector. In addition, the free zones have been given the most emphasis as state incentives have been on the rise ( Çalık Gayrimenkul 2013- 2014 Report and Cushman\&Wakefield 2013-2014 Construction Market Research Report)

\section{Literature Review on Marketing Tips for the Enhancement of the}

\section{Services Sector}

Before starting the literature review in this part, it is assumed that construction sectors marketing strategies should be revealed under services sector. In this globe, it can be declared that above matters concerning the Turkish economy should well be revealed when a marketing strategy is being implemented. This is to say that not enough generic marketing strategies have been adapted to the Turkish Construction sector, thus this research may be a guide for future marketing strategies to be implemented. However, marketing is about meeting and exceeding the consumer expectations. In this sense, the whole aspect of marketing should be focused upon meeting the changing needs of the consumer groups (Armstrong and Kotler, 2001:4). It is debated that as construction business acts on behalf of services industry, service expectations and quality should be increased. In this perspective, one of the best tool for success is to establish service quality standards for construction companies that serve the needs of the markets. Çavuşgil states that this is critical especially in terms of differentiating the services from competitors (Çavuşgil, 1985:3). Etzel states that it is important to research the market in terms of macro and micro environmental factors. Thus it may be stated that one of the best marketing tip would be to analyze the sector before establishing competition strategies (Etzel, 1997:26). On the other hand, Winer states that a comparative analysis in terms of cost and demand initiatives on the services sector should be revealed on the mission of establishing corporate marketing strategies. This is to say that emerging marketing trends and applications should be utilized( Winer, 2000:48). Besides, it is believed that sustainability and environment friendliness are the two major issues of concern in the context of management skills (Kassaye, 2001:3). Another research depicts that ecological factors play a crucial role in the strategy formation in many competitive markets ( 
Gittell, Magnusson, and Merenda, 2012: 67). In addition, according to the International Standardization Organization, it is debated that sustainable development is based upon innovation, efficiency, and service quality ( www.iso.org/iso). At all cases, it is definite that marketing activities play a crucial role in strategy formation and its importance should be understood well in order to meet the changing needs of consumers (Karafakıoglu, 2006:132). In addition, Peppers and Rogers argue that managing customer relations are important in order to create a level of differentiation in the services being offered. The authors state that the processes should be aligned with each other to lower the cost of production and delivery( Peppers and Rogers, 2011:4). However, it is explained in literature that it is important to monitor the costs that are associated with production, distribution, and the market (Christopher, 1998: 12)

\section{Literature Review on Online Marketing Tips as an Alternative Means to Increase Marketing Efficiency in the Service Sector}

This paper simultaneously discusses the use of online techniques in order to increase the efficiency of marketing trends in the construction sector. It may be discussed that online marketing is the best alternative to classical market which in the long run reduces the costs associated with the sector as well. Barnes discusses that online marketing may interfere with the permission marketing aspects of general marketing trends, thus the author states that the procedures that define the online marketing should be met (Barnes, 2002:14). On the other side, Barutçu declares that several attitudes towards mobile marketing consumers should studied before attempting to generate a marketing plan as he says that this may be crucial in terms of strategy formation (Barutçu, 2007:27). In addition, Bhatti discusses that mobile commerce is widely used in services as a means to support the ongoing marketing practices ( Bhatti, 2007: 11).On the other side, Chen, Ross, and Huang discusses that privacy, trust, and justice considerations are the three driving factors in how services marketing strategies may be implemented online. Thus the authors offer a theoretical model to justify their point of view. ( Chen, Ross, and Huang, 2002:39). However, Chen debates that mobile payment is a big concern for the consumers as consumer acceptance level may differentiate based on the perception of the target groups. Thus, the author brings out a model of study as a means to justify his point of interest where he discusses several variables that define consumer acceptance levels ( Chen, 2008:41). Finally, Denk and Hackl, in their research paper, try to investigate the future of online marketing and state that mobile business is endless as technology and innovation is always on the rise (Denk and Hackl, 2004: 480). 


\section{Perception of The Construction Sector In Turkey}

\section{Method}

\section{Sample}

The research sample is composed of 152 subjects. Socio-demographic information (gender, age, education level and work experience) is summarized in Table 1.

Table 1: Socio-Demographic Information

\begin{tabular}{lccc}
\hline Variable & Group & $\mathbf{N}$ & $\%$ \\
\hline Gender & Female & 20 & 13,2 \\
& Male & 132 & 86,8 \\
Age & $21-40$ years & 83 & 54,6 \\
& $>40$ years & 69 & 45,4 \\
Education Level & $>11$ years & 108 & 71,1 \\
& $\leq 11$ years & 44 & 28,9 \\
Work Experience & $0-5$ years & 39 & 25,7 \\
& $>5$ years & 113 & 74,3 \\
\hline
\end{tabular}

\section{Instrument}

The research sample is given a survey form prepared by the researcher. The survey form is composed of 6 items that questions the subjects concerning their views about the construction sector and economy in Turkey. In Table 2, a copy of the survey form is provided. 
Table 2: Survey Form

\section{Questions}

1 Sizce Türkiye ekonomisi önümüzdeki 10 yılda da büyümeye devam edecek midir?

2 Sizce inşaat sektörü önümüzdeki 10 yılda da büyümeye devam edecek midir?

3 Türkiye'de inşaat sektöründe en çok hangi tür inşaat yapılmaktadır?

Sizce önümüzdeki 10 yılda Türkiye'deki inşaat firmalarının en büyük pazarı hangi ülkelerde olacaktır?

a. Orta Doğu

a. Evet

b. Hayır

c. Emin değilim
a. Evet
b. Hayır
c. Emin değilim

a. Emlak

b. Turistik yap1

c.Otoyol/Köprü/

Tünel/Liman,etc. re

5 Sizce Tükiye'deki inşaat firmalarının stratejilerinde en çok öne çıkarmaları gereken nokta hangisidir? b. Kuzey Afrika

c. Asya-Avrupa

c. Kurumsal

b. Yenilikçilik ve yeni ürün geliştirme

6 Sizce Türkiye'de inşaat sektöründeki en önemli sorun nedir?

\section{Data Analysis}

The data collected from the research sample is analyzed using SPSS statistical analysis program. The data analysis is done in two steps. In the first step the descriptive statistics for the items of the survey form are calculated. In the second step group comparison and correlation analysis according to the socio-demographic variables are done.

\section{Results and Concluding Remarks}

The descriptive statistics for each of the survey question is given in Table 3. It is seen that in question 1 (Sizce Türkiye ekonomisi önümüzdeki 10 yılda da büyümeye devam edecek midir?) 96,7\% of the subjects, in question 2 (Sizce inşaat sektörü önümüzdeki 10 yılda da büyümeye devam edecek midir?) $91,4 \%$ of the subjects answered the question positively, as "Yes".

In question 3 (Türkiye'de inşaat sektöründe en çok hangi tür inşaat yapılmaktadır?) "Emlak" is stated by the $87,5 \%$ of the subjects, "Turistik yapı" by the $18,4 \%$ of the subjects and “Otoyol/Köprü/Tünel/Liman,etc.” by the $15,1 \%$ of the subjects. 
In question 4 (Sizce önümüzdeki 10 yılda Türkiye'deki inşaat firmalarının en büyük pazarı hangi ülkelerde olacaktır?) "Orta Doğu" is stated by the $95,4 \%$ of the subjects, "Kuzey Afrika" by the $88,2 \%$ of the subjects and "Asya-Avrupa" by the $3,9 \%$ of the subjects.

In question 5 (Sizce Tükiye'deki inşaat firmalarının stratejilerinde en çok öne çıkarmaları gereken nokta hangisidir?) "Satış yollarını artırma" is stated by the $96,7 \%$ of the subjects, "Yenilikçilik ve yeni ürün geliştirme" by the $96,1 \%$ of the subjects and "Kurumsal kültürü ve operasyonel işleyişi geliştirme" by the $2,6 \%$ of the subjects.

In question 6 (Sizce Türkiye'de inşaat sektöründeki en önemli sorun nedir?) "Kalitesiz Yapılar" is stated by the 21,7\% of the subjects, "Maliyet" by the 17,8 of the subjects, "Devlet Politikaları by the 13,8 of the subjects, "Haksız Rekabet" by the 12,5 of the subjects, "İş/Kariyer Olanakları Eksikliği" by the $11,8 \%$ of the subjects, and "İstihdam" by the $11,2 \%$ of the subjects.

Table 3: Descriptive Statistics for the Survey Questions

\begin{tabular}{|c|c|c|c|c|c|}
\hline Q1 & $\mathbf{N}$ & $\%$ & Q2 & $\mathbf{N}$ & $\%$ \\
\hline a. Evet & 147 & 96,7 & a. Evet & 139 & 91,4 \\
\hline b. Hayır & 5 & 3,3 & b. Hayır & 13 & 8,6 \\
\hline c. Emin değilim & 0 & 0 & c. Emin değilim & 0 & 0 \\
\hline Q3 & $\mathbf{N}$ & $\%$ & Q4 & $\mathbf{N}$ & $\%$ \\
\hline a. Emlak & 133 & 87,5 & a. Orta Doğu & 145 & 95,4 \\
\hline b. Turistik yapı & 28 & 18,4 & b. Kuzey Afrika & 134 & 88,2 \\
\hline c. Otoyol/Köprü/Tünel/Liman,etc. & 23 & 15,1 & c. Asya-Avrupa & 6 & 3,9 \\
\hline Q5 & $\mathbf{N}$ & $\%$ & Q6 & $\mathbf{N}$ & $\%$ \\
\hline a. Satış yollarını artırma & 147 & 96,7 & Devlet Politikaları & 21 & 13,8 \\
\hline b. Yenilikçilik ve yeni ürün geliştirme & 146 & 96,1 & Haksız Rekabet & 19 & 12,5 \\
\hline \multirow{5}{*}{$\begin{array}{l}\text { c. Kurumsal kültürü ve operasyonel işleyişi } \\
\text { geliştirme }\end{array}$} & 4 & 2,6 & İnşaat Firmalarının Artması & 1 & 0,7 \\
\hline & & & İstihdam & 17 & 11,2 \\
\hline & & & İstikrarsızlık & 13 & 8,6 \\
\hline & & & İş/Kariyer Olanakları Eksikliği & 16 & 11,8 \\
\hline & & & Kalitesiz Yapılar & 33 & 21,7 \\
\hline
\end{tabular}


In socio-demographic group comparisons gender, age, education level and work experience groups are compared for each of the survey question.

Table 4: Comparison of Gender Groups

\begin{tabular}{|c|c|c|c|c|c|}
\hline Crosstabulation & Gender & Q1 & Evet & Hayır & Chi-Square \\
\hline & & $\mathrm{N}$ & 129 & 3 & \\
\hline & Male & & & & $\chi_{(1)}^{2}=3,260$ \\
\hline Gender* & & $\%$ within Gender & $97,7 \%$ & $2,3 \%$ & \\
\hline \multirow[t]{6}{*}{ Q1 Ekonomi - Büyüme } & & $\mathrm{N}$ & 18 & 2 & \\
\hline & Female & & & & $p=0.071$ \\
\hline & & $\%$ within Gender & $90,0 \%$ & $10,0 \%$ & \\
\hline & & Q2 & Evet & Hayır & \\
\hline & & $\mathrm{N}$ & 126 & 6 & \\
\hline & Male & & & & $\chi_{(1)}^{2}=20,597$ \\
\hline Gender* & & $\%$ within Gender & $95,5 \%$ & $4,5 \%$ & \\
\hline \multirow[t]{6}{*}{ Q2 İnşaat - Büyüme } & & $\mathrm{N}$ & 13 & 7 & \\
\hline & Female & & & & $p=0.000$ \\
\hline & & $\%$ within Gender & $65,0 \%$ & $35,0 \%$ & \\
\hline & & Q3a. & Evet & Hayır & \\
\hline & & $\mathrm{N}$ & 116 & 16 & \\
\hline & Male & & & & $x_{(1)}^{2}=0,132$ \\
\hline Gender * & & $\%$ within Gender & $87,9 \%$ & $12,1 \%$ & \\
\hline \multirow[t]{6}{*}{ Q3 a. Emlak } & & $\mathrm{N}$ & 17 & 3 & \\
\hline & Female & & & & $p=0.717$ \\
\hline & & $\%$ within Gender & $85,0 \%$ & $15,0 \%$ & \\
\hline & & Q3b. & Evet & Hayır & \\
\hline & & $\mathrm{N}$ & 23 & 109 & \\
\hline & Male & & & & $\chi_{(1)}^{2}=0,663$ \\
\hline Gender * & & $\%$ within Gender & $17,4 \%$ & $82,6 \%$ & \\
\hline \multirow[t]{3}{*}{ Q3 b. Turistik Yapı } & & $\mathrm{N}$ & 5 & 15 & \\
\hline & Female & & & & $p=0.415$ \\
\hline & & $\%$ within Gender & $25,0 \%$ & $75,0 \%$ & \\
\hline
\end{tabular}




\begin{tabular}{|c|c|c|c|c|c|}
\hline & & Q3c. & Evet & Hayır & \\
\hline & & $\mathrm{N}$ & 16 & 116 & \\
\hline \multirow[t]{2}{*}{ Gender * } & Male & & & & $\chi_{(1)}^{2}=7,079$ \\
\hline & & $\%$ within Gender & $12,1 \%$ & $87,9 \%$ & \\
\hline \multicolumn{6}{|l|}{ Q3 c. Otoyol/Köprü/ } \\
\hline & & $\mathrm{N}$ & 7 & 13 & \\
\hline \multirow[t]{5}{*}{ Tünel/Liman, etc. } & Female & & & & $p=0.008$ \\
\hline & & $\%$ within Gender & $35,0 \%$ & $65,0 \%$ & \\
\hline & & Q4a. & Evet & Hayır & \\
\hline & & $\mathrm{N}$ & 128 & 4 & \\
\hline & Male & & & & $\chi_{(1)}^{2}=5,664$ \\
\hline Gender * & & $\%$ within Gender & $97,0 \%$ & $3,0 \%$ & \\
\hline \multirow[t]{6}{*}{ Q4 a. Orta Doğu } & & $\mathrm{N}$ & 17 & 3 & \\
\hline & Female & & & & $p=0.017$ \\
\hline & & $\%$ within Gender & $85,0 \%$ & $15,0 \%$ & \\
\hline & & Q4b. & Evet & Hayır & \\
\hline & & $\mathrm{N}$ & 116 & 16 & \\
\hline & Male & & & & $\chi_{(1)}^{2}=0,075$ \\
\hline Gender * & & $\%$ within Gender & $87,9 \%$ & $12,1 \%$ & \\
\hline \multirow[t]{6}{*}{ Q4 b. Kuzey Afrika } & & $\mathrm{N}$ & 18 & 2 & \\
\hline & Female & & & & $p=0.784$ \\
\hline & & $\%$ within Gender & $90,0 \%$ & $10,0 \%$ & \\
\hline & & Q4c. & Evet & Hayır & \\
\hline & & $\mathrm{N}$ & 3 & 129 & \\
\hline & Male & & & & $\chi_{(1)}^{2}=7,420$ \\
\hline Gender* & & $\%$ within Gender & $2,3 \%$ & $97,7 \%$ & \\
\hline \multirow[t]{3}{*}{ Q4 c. Asya-Avrupa } & & $\mathrm{N}$ & 3 & 17 & \\
\hline & Female & & & & $p=0.006$ \\
\hline & & $\%$ within Gender & $15,0 \%$ & $85,0 \%$ & \\
\hline
\end{tabular}

Table 4: Comparison of Gender Groups (continued)

\begin{tabular}{lllccc}
\hline Crosstabulation & Gender & Q5a. & Evet & Hayır & Chi-Square \\
& Male & N & 128 & 4 & $\chi^{2}{ }_{(1)}=0,212$ \\
Gender * & & $\%$ within Gender & $97,0 \%$ & $3,0 \%$ & \\
Q5a. Satış yollarını artırma & & $\mathrm{N}$ & 19 & 1 & $\mathrm{p}=0.645$ \\
& Female & \% within Gender & $95,0 \%$ & $5,0 \%$ & \\
\hline
\end{tabular}




\begin{tabular}{|c|c|c|c|c|c|}
\hline & & Q5b. & Evet & Hayır & \\
\hline \multirow{3}{*}{ Gender * } & \multirow{3}{*}{ Male } & $\mathrm{N}$ & 129 & 3 & \multirow{3}{*}{$\chi_{(1)}^{2}=7,420$} \\
\hline & & & & & \\
\hline & & $\%$ within Gender & $97,7 \%$ & $2,3 \%$ & \\
\hline \multirow{4}{*}{$\begin{array}{l}\text { Q5b. Yenilikçilik ve yeni ürün } \\
\text { geliştirme }\end{array}$} & \multirow{3}{*}{ Female } & $\mathrm{N}$ & 17 & \multirow{2}{*}{3} & \multirow{3}{*}{$p=0.006$} \\
\hline & & & & & \\
\hline & & $\%$ within Gender & $85,0 \%$ & $15,0 \%$ & \\
\hline & & Q5c. & Evet & Hayır & \\
\hline \multirow{3}{*}{ Gender * } & \multirow{3}{*}{ Male } & $\mathrm{N}$ & 1 & 131 & \multirow{3}{*}{$\chi_{(1)}^{2}=13,750$} \\
\hline & & & & & \\
\hline & & $\%$ within Gender & $0,8 \%$ & $99,2 \%$ & \\
\hline \multirow{3}{*}{$\begin{array}{l}\text { Q5c. Kurumsal kültürü ve } \\
\text { operasyonel işleyişi } \\
\text { geliştirme }\end{array}$} & & $\mathrm{N}$ & 3 & 17 & \multirow{3}{*}{$p=0.000$} \\
\hline & Female & & & & \\
\hline & & $\%$ within Gender & $15,0 \%$ & $85,0 \%$ & \\
\hline
\end{tabular}

The Chi-Square comparisons of the gender groups are given in Table 4 . It is found that in questions Q1, Q3a., Q3b., Q4b., Q5a. there is no statistically significant difference between the gender groups.

In question Q2 males $(\chi 2(1)=20,597, p=0.000)$, Q3c. females $(\chi 2(1)=7,079, p=0.008), Q 4 a$. males $(\chi 2(1)=5,664, p=0.017), Q 4 c$. females $(\chi 2(1)=7,420, p=0.006)$, Q5b. males $(\chi 2(1)=$ $7,420, p=0.006)$, and Q5c. females $(\chi 2(1)=13,750, p=0.000)$ showed statistically significantly higher percentages in the answer "Yes" compared to the other gender.

Table 5: Comparison of Age Groups

\begin{tabular}{|c|c|c|c|c|c|}
\hline Crosstabulation & Gender & Q1 & Evet & Hayır & Chi-Square \\
\hline Age * & $\begin{array}{l}21-40 \\
\text { years }\end{array}$ & $\%$ within Age & $96,4 \%$ & $3,6 \%$ & $\chi_{(1)}^{2}=0,061$ \\
\hline \multirow[t]{2}{*}{ Q1 Ekonomi - Büyüme } & $\begin{array}{l}>40 \\
\text { years }\end{array}$ & $\%$ within Age & 67 & $2,9 \%$ & $p=0.805$ \\
\hline & & Q2 & Evet & Hayır & \\
\hline Age * & $\begin{array}{l}21-40 \\
\text { years }\end{array}$ & $\%$ within Age & $92,8 \%$ & $7,2 \%$ & $\chi_{(1)}^{2}=0,410$ \\
\hline Q2 İnşaat - Büyüme & $>40$ & $\mathrm{~N}$ & 62 & 7 & $p=0.522$ \\
\hline
\end{tabular}




\begin{tabular}{|c|c|c|c|c|c|}
\hline & years & $\%$ within Age & $89,9 \%$ & $10,1 \%$ & \\
\hline & & Q3a. & Evet & Hayır & \\
\hline & $21-40$ & $\mathrm{~N}$ & 75 & 8 & $v^{2}-1360$ \\
\hline Age * & years & $\%$ within Age & $90,4 \%$ & $9,6 \%$ & $X(1)-1,505$ \\
\hline \multirow[t]{3}{*}{ Q3 a. Emlak } & $>40$ & $\mathrm{~N}$ & 58 & 11 & \multirow{2}{*}{$p=0.242$} \\
\hline & years & $\%$ within Age & $84,1 \%$ & $15,9 \%$ & \\
\hline & & Q3b. & Evet & Hayır & \\
\hline \multirow[b]{2}{*}{ Age * } & $21-40$ & $\mathrm{~N}$ & 12 & 71 & \multirow{2}{*}{$\chi_{(1)}^{2}=1,911$} \\
\hline & years & $\%$ within Age & $14,5 \%$ & $85,5 \%$ & \\
\hline \multirow[t]{3}{*}{ Q3 b. Turistik Yapı } & $>40$ & $\mathrm{~N}$ & 16 & 53 & \multirow{2}{*}{$p=0.167$} \\
\hline & years & $\%$ within Age & $23,2 \%$ & $76,8 \%$ & \\
\hline & & Q3c. & Evet & Hayır & \\
\hline \multirow{2}{*}{ Age * } & $21-40$ & $\mathrm{~N}$ & 8 & 75 & \multirow{2}{*}{$\chi_{(1)}^{2}=4,296$} \\
\hline & years & $\%$ within Age & $9,6 \%$ & $90,4 \%$ & \\
\hline \multicolumn{6}{|l|}{ Q3 c. Otoyol/Köprü/ } \\
\hline \multirow{3}{*}{ Tünel/Liman, etc. } & $>40$ & $\mathrm{~N}$ & 15 & 54 & \multirow{2}{*}{$p=0.038$} \\
\hline & years & $\%$ within Age & $21,7 \%$ & $78,3 \%$ & \\
\hline & & Q4a. & Evet & Hayır & \\
\hline & $21-40$ & $\mathrm{~N}$ & 80 & 3 & \\
\hline Age $^{*}$ & years & $\%$ within Age & $96,4 \%$ & $3,6 \%$ & \\
\hline \multirow[t]{3}{*}{ Q4 a. Orta Doğu } & $>40$ & $\mathrm{~N}$ & 65 & 4 & \multirow{2}{*}{$p=0.523$} \\
\hline & years & $\%$ within Age & $94,2 \%$ & $5,8 \%$ & \\
\hline & & Q4b. & Evet & Hayır & \\
\hline & $21-40$ & $\mathrm{~N}$ & 76 & 7 & ב20 - \\
\hline Age $^{*}$ & years & $\%$ within Age & $91,6 \%$ & $8,4 \%$ & $(1)=2$, U35 \\
\hline \multirow[t]{3}{*}{ Q4 b. Kuzey Afrika } & $>40$ & $\mathrm{~N}$ & 58 & 11 & \multirow{2}{*}{$p=0.154$} \\
\hline & years & $\%$ within Age & $84,1 \%$ & $15,9 \%$ & \\
\hline & & Q4c. & Evet & Hayır & \\
\hline
\end{tabular}




\begin{tabular}{|c|c|c|c|c|c|}
\hline & $21-40$ & $\mathrm{~N}$ & 3 & 80 & $\chi_{(1)}^{2}=0,053$ \\
\hline Age * & years & $\%$ within Age & $3,6 \%$ & $96,4 \%$ & \\
\hline \multirow[t]{2}{*}{ Q4 c. Asya-Avrupa } & $>40$ & $\mathrm{~N}$ & 3 & 66 & \multirow{2}{*}{$p=0.817$} \\
\hline & years & $\%$ within Age & $4,3 \%$ & $95,7 \%$ & \\
\hline
\end{tabular}

Table 5: Comparison of Age Groups (continued)

\begin{tabular}{|c|c|c|c|c|c|}
\hline Crosstabulation & Gender & Q5a. & Evet & Hayır & Chi-Square \\
\hline & $21-40$ & $\mathrm{~N}$ & 81 & 2 & $x^{2}$ \\
\hline Age * & years & $\%$ within Age & $97,6 \%$ & $2,4 \%$ & \\
\hline \multirow[t]{3}{*}{ Q5a. Satış yollarını artırma } & $>40$ & $\mathrm{~N}$ & 66 & 3 & \multirow{2}{*}{$p=0.505$} \\
\hline & years & $\%$ within Age & $95,7 \%$ & $4,3 \%$ & \\
\hline & & Q5b. & Evet & Hayır & \\
\hline \multirow[b]{2}{*}{ Age $^{*}$} & $21-40$ & $\mathrm{~N}$ & 79 & 4 & \multirow{2}{*}{$\chi_{(1)}^{2}=0,367$} \\
\hline & years & $\%$ within Age & $95,2 \%$ & $4,8 \%$ & \\
\hline \multirow{3}{*}{$\begin{array}{l}\text { Q5b. Yenilikçilik ve yeni ürün } \\
\text { geliştirme }\end{array}$} & $>40$ & $\mathrm{~N}$ & 67 & 2 & \multirow{2}{*}{$p=0.545$} \\
\hline & years & $\%$ within Age & $97,1 \%$ & $2,9 \%$ & \\
\hline & & Q5c. & Evet & Hayır & \\
\hline \multirow[b]{2}{*}{ Age * } & $21-40$ & $\mathrm{~N}$ & 2 & 81 & \multirow{2}{*}{$\chi_{(1)}^{2}=0,035$} \\
\hline & years & $\%$ within Age & $2,4 \%$ & $97,6 \%$ & \\
\hline \multirow{2}{*}{$\begin{array}{l}\text { Q5c. Kurumsal kültürü ve } \\
\text { operasyonel işleyişi } \\
\text { geliştirme }\end{array}$} & $>40$ & $\mathrm{~N}$ & 2 & 67 & \multirow{2}{*}{$p=0.851$} \\
\hline & years & $\%$ within Age & $2,9 \%$ & $97,1 \%$ & \\
\hline
\end{tabular}

The Chi-Square comparisons of the age groups are given in Table 5. It is found that in questions Q1, Q2, Q3a., Q3b., Q4a, Q4b., Q4c, Q5a., Q5b, Q5c there is no statistically significant difference between the age groups. 
In question $\mathrm{Q} 3 \mathrm{c},>40$ years group $(\chi 2(1)=4,296, \mathrm{p}=0.038)$ showed statistically significantly higher percentage in the answer "Yes" compared to the 21-40 years group.

Table 6: Comparison of Education Level Groups

\begin{tabular}{|c|c|c|c|c|c|}
\hline Crosstabulation & Gender & Q1 & Evet & Hayır & Chi-Square \\
\hline & & $\mathrm{N}$ & 41 & 3 & \\
\hline & $\leq 11$ years & & & & $\chi_{(1)}^{2}=2,424$ \\
\hline Education Level* & & $\%$ within Education & $93,2 \%$ & $6,8 \%$ & \\
\hline \multirow[t]{6}{*}{ Q1 Ekonomi - Büyüme } & & $\mathrm{N}$ & 106 & 2 & \\
\hline & $>11$ years & & & & $p=0.120$ \\
\hline & & $\%$ within Education & $98,1 \%$ & $1,9 \%$ & \\
\hline & & Q2 & Evet & Hayır & \\
\hline & & $\mathrm{N}$ & 39 & 5 & \\
\hline & $\leq 11$ years & & & & $\chi_{(1)}^{2}=0,626$ \\
\hline Education Level * & & $\%$ within Education & $88,6 \%$ & $11,4 \%$ & \\
\hline \multirow[t]{4}{*}{ Q2 İnşaat - Büyüme } & & $\mathrm{N}$ & 100 & 8 & \\
\hline & $>11$ years & & & & $p=0.429$ \\
\hline & & $\%$ within Education & $92,6 \%$ & $7,4 \%$ & \\
\hline & & Q3a. & Evet & Hayır & \\
\hline & & $\mathrm{N}$ & 40 & 4 & \\
\hline & $\leq 11$ years & & & & $\chi_{(1)}^{2}=0,658$ \\
\hline Education Level * & & $\%$ within Education & $90,9 \%$ & $9,1 \%$ & \\
\hline \multirow[t]{4}{*}{ Q3 a. Emlak } & & $\mathrm{N}$ & 93 & 15 & \\
\hline & $>11$ years & & & & $p=0.417$ \\
\hline & & $\%$ within Education & $86,1 \%$ & $13,9 \%$ & \\
\hline & & Q3b. & Evet & Hayır & \\
\hline & & $\mathrm{N}$ & 6 & 38 & \\
\hline & $\leq 11$ years & & & & $\chi_{(1)}^{2}=0,943$ \\
\hline Education Level * & & $\%$ within Education & $13,6 \%$ & $86,4 \%$ & \\
\hline \multirow[t]{4}{*}{ Q3 b. Turistik Yapı } & & $\mathrm{N}$ & 22 & 86 & \\
\hline & $>11$ years & & & & $p=0.331$ \\
\hline & & $\%$ within Education & $20,4 \%$ & $79,6 \%$ & \\
\hline & & Q3c. & Evet & Hayır & \\
\hline Education Level * & & $\mathrm{N}$ & 11 & 33 & \\
\hline & $\leq 11$ years & & & & $\chi_{(1)}^{2}=4,696$ \\
\hline Q3 c. Otoyol/Köprü/ & & $\%$ within Education & $25,0 \%$ & $75,0 \%$ & \\
\hline
\end{tabular}


Tünel/Liman, etc.

$\mathrm{N}$

$>11$ years

$\%$ within Education
12

$11,1 \%$
96

$88,9 \%$ $p=0.030$

Hayır

4

$\chi_{(1)}^{2}=2,836$

Education Level *

$\leq 11$ years

\% within Education

$90,9 \%$

$9,1 \%$

Q4 a. Orta Doğu

N

105

$>11$ years

$\%$ within Education

$97,2 \%$

Evet

Hayır

33

11

$\leq 11$ years

Education Level *

\% within Education

$75,0 \%$

$\chi_{(1)}^{2}=10,270$

Q4 b. Kuzey Afrika

$>11$ years

N

$\%$ within Education

101

$93,5 \%$

$p=0.001$

$$
p=0.092
$$

\begin{tabular}{|c|c|c|c|c|c|}
\hline & & Q4c. & Evet & Hayır & \\
\hline & & $\mathrm{N}$ & 3 & 41 & \\
\hline & $\leq 11$ years & & & & $\chi_{(1)}^{2}=1,346$ \\
\hline Education Level * & & $\%$ within Education & $6,8 \%$ & $93,2 \%$ & \\
\hline \multirow[t]{2}{*}{ Q4 c. Asya-Avrupa } & & $N$ & 3 & 105 & \\
\hline & & $\%$ within Education & $2,8 \%$ & $97,2 \%$ & \\
\hline
\end{tabular}

Table 6: Comparison of Education Level Groups (continued)

\begin{tabular}{|c|c|c|c|c|c|}
\hline Crosstabulation & Gender & Q5a. & Evet & Hayır & Chi-Square \\
\hline \multirow[b]{2}{*}{ Education Level * } & \multirow[b]{2}{*}{$\leq 11$ years } & $\mathrm{N}$ & 39 & 5 & \multirow[b]{2}{*}{$\chi_{(1)}^{2}=12,690$} \\
\hline & & $\%$ within Education & $88,6 \%$ & $11,4 \%$ & \\
\hline \multirow{4}{*}{$\begin{array}{l}\text { Q5a. Satış yollarını } \\
\text { artırma }\end{array}$} & \multirow{3}{*}{$>11$ years } & $\mathrm{N}$ & 108 & \multirow[t]{2}{*}{0} & \multirow{3}{*}{$p=0.000$} \\
\hline & & & & & \\
\hline & & $\%$ within Education & $100,0 \%$ & $0,0 \%$ & \\
\hline & & Q5b. & Evet & Hayır & \\
\hline Education Level * & $\leq 11$ years & $\mathrm{N}$ & 41 & 3 & \multirow[t]{2}{*}{$\chi_{(1)}^{2}=1,342$} \\
\hline 05 h Yenilikcilik ve & & $\%$ within Education & $93,2 \%$ & $6,8 \%$ & \\
\hline
\end{tabular}




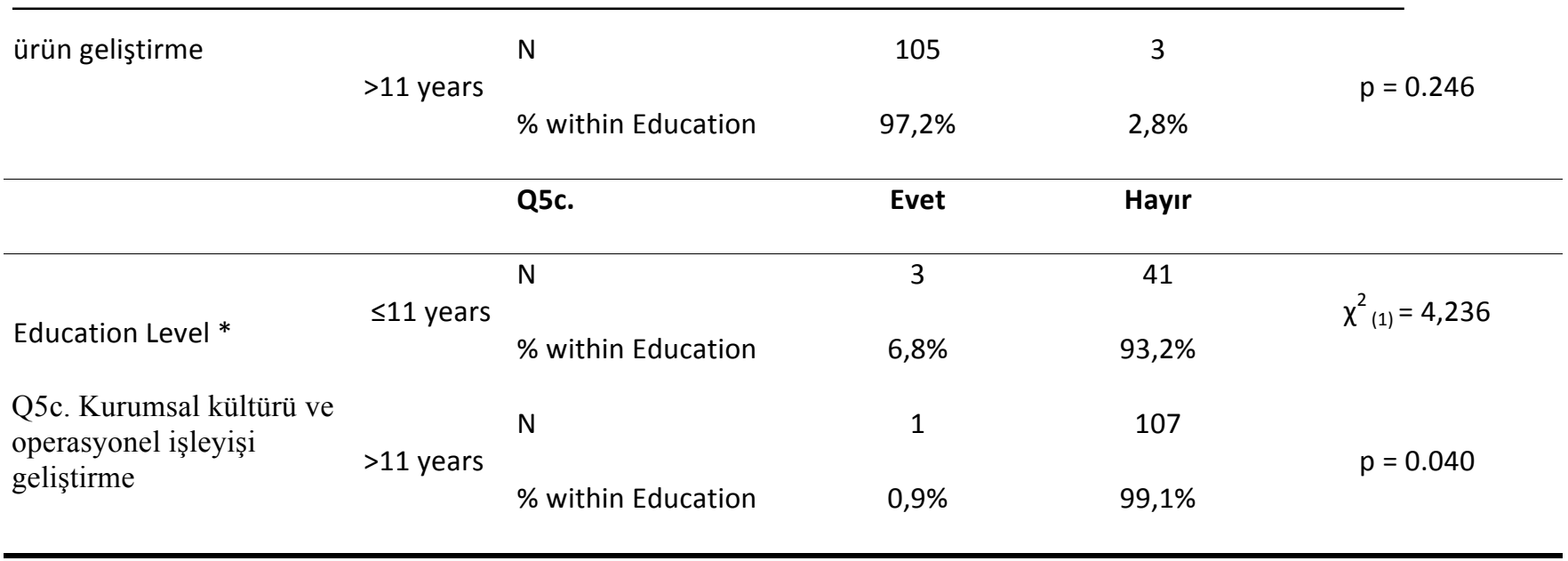

The Chi-Square comparisons of the education level groups are given in Table 6. It is found that in questions Q1, Q2, Q3a., Q3b., Q4a, Q4c., Q5b. there is no statistically significant difference between the education level groups.

In question Q3c. $\leq 11$ years group $(\chi 2(1)=4,696, \mathrm{p}=0.030), \mathrm{Q} 4 \mathrm{~b} .>11$ years group $(\chi 2(1)=$ $10,270, \mathrm{p}=0.001)$, Q5a. $>11$ years group $(\chi 2(1)=12,690, \mathrm{p}=0.000), \mathrm{Q} 5 \mathrm{c} . \leq 11$ years group $(\chi 2$ $(1)=4,236, p=0.040)$, showed statistically significantly higher percentages in the answer "Yes" compared to the other education level group.

Table 7: Comparison of Work Experience Groups

\begin{tabular}{|c|c|c|c|c|c|}
\hline Crosstabulation & Gender & Q1 & Evet & Hayır & Chi-Square \\
\hline & & $\mathrm{N}$ & 38 & 1 & \\
\hline & $0-5$ years & & & & $\chi_{(1)}^{2}=0,087$ \\
\hline Work Experience * & & $\%$ within Work & $97,4 \%$ & $2,6 \%$ & \\
\hline \multirow[t]{6}{*}{ Q1 Ekonomi - Büyüme } & & $\mathrm{N}$ & 109 & 4 & \\
\hline & $>5$ years & & & & $p=0.768$ \\
\hline & & $\%$ within Work & $96,5 \%$ & $3,5 \%$ & \\
\hline & & Q2 & Evet & Hayır & \\
\hline & & $\mathrm{N}$ & 37 & 2 & \\
\hline & $0-5$ years & & & & $\chi_{(1)}^{2}=0,787$ \\
\hline Work Experience * & & $\%$ within Work & $94,9 \%$ & $5,1 \%$ & \\
\hline \multirow[t]{3}{*}{ Q2 İnşaat - Büyüme } & & $\mathrm{N}$ & 102 & 11 & \\
\hline & $>5$ years & & & & $p=0.375$ \\
\hline & & \% within Work & $90,3 \%$ & $9,7 \%$ & \\
\hline
\end{tabular}




\begin{tabular}{|c|c|c|c|c|c|}
\hline & & $\mathrm{N}$ & 36 & 3 & \\
\hline & $0-5$ years & & & & $\chi_{(1)}^{2}=1,109$ \\
\hline Work Experience * & & $\%$ within Work & $92,3 \%$ & $7,7 \%$ & \\
\hline \multirow[t]{6}{*}{ Q3 a. Emlak } & & $\mathrm{N}$ & 97 & 16 & \\
\hline & $>5$ years & & & & $p=0.292$ \\
\hline & & $\%$ within Work & $85,8 \%$ & $14,2 \%$ & \\
\hline & & Q3b. & Evet & Hayır & \\
\hline & & $\mathrm{N}$ & 6 & 33 & \\
\hline & $0-5$ years & & & & $\chi_{(1)}^{2}=0,322$ \\
\hline Work Experience * & & $\%$ within Work & $15,4 \%$ & $84,6 \%$ & \\
\hline \multirow[t]{4}{*}{ Q3 b. Turistik Yapı } & & $\mathrm{N}$ & 22 & 91 & \\
\hline & $>5$ years & & & & $p=0.570$ \\
\hline & & $\%$ within Work & $19,5 \%$ & $80,5 \%$ & \\
\hline & & Q3c. & Evet & Hayır & \\
\hline \multirow{3}{*}{ Work Experience * } & & $\mathrm{N}$ & 5 & 34 & \\
\hline & $0-5$ years & & & & $\chi_{(1)}^{2}=0,218$ \\
\hline & & $\%$ within Work & $12,8 \%$ & $87,2 \%$ & \\
\hline \multicolumn{6}{|l|}{ Q3 c. Otoyol/Köprü/ } \\
\hline & & $\mathrm{N}$ & 18 & 95 & \\
\hline \multirow[t]{2}{*}{ Tünel/Liman, etc. } & $>5$ years & & & & $p=0.640$ \\
\hline & & $\%$ within Work & $15,9 \%$ & $84,1 \%$ & \\
\hline
\end{tabular}

\begin{tabular}{|c|c|c|c|c|c|}
\hline & & Q4a. & Evet & Hayır & \\
\hline & & $\mathrm{N}$ & 36 & 3 & \\
\hline & $0-5$ years & & & & $\chi_{(1)}^{2}=1,138$ \\
\hline Work Experience * & & $\%$ within Work & $92,3 \%$ & $7,7 \%$ & \\
\hline \multirow[t]{6}{*}{ Q4 a. Orta Doğu } & & $\mathrm{N}$ & 109 & 4 & \\
\hline & $>5$ years & & & & $p=0.286$ \\
\hline & & $\%$ within Work & $96,5 \%$ & $3,5 \%$ & \\
\hline & & Q4b. & Evet & Hayır & \\
\hline & & $\mathrm{N}$ & 32 & 7 & \\
\hline & $0-5$ years & & & & $\chi_{(1)}^{2}=1,874$ \\
\hline Work Experience * & & $\%$ within Work & $82,1 \%$ & $17,9 \%$ & \\
\hline \multirow[t]{4}{*}{ Q4 b. Kuzey Afrika } & & $\mathrm{N}$ & 102 & 11 & \\
\hline & $>5$ years & & & & $p=0.171$ \\
\hline & & $\%$ within Work & $90,3 \%$ & $9,7 \%$ & \\
\hline & & Q4c. & Evet & Hayır & \\
\hline Work Experience * & & $\mathrm{N}$ & 3 & 36 & \\
\hline & $0-5$ years & & & & $\chi_{(1)}^{2}=1,940$ \\
\hline Q4 c. Asya-Avrupa & & $\%$ within Work & $7,7 \%$ & $92,3 \%$ & \\
\hline
\end{tabular}




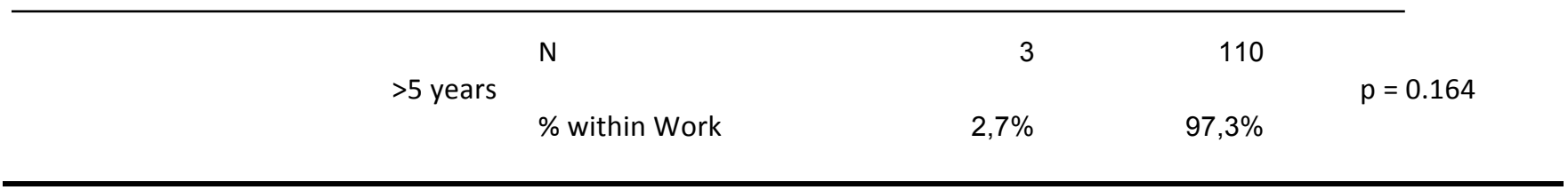

Table 7: Comparison of Work Experience Groups (continued)

\begin{tabular}{|c|c|c|c|c|c|}
\hline Crosstabulation & Gender & Q5a. & Evet & Hayır & Chi-Square \\
\hline & & $\mathrm{N}$ & 36 & 3 & \\
\hline & $0-5$ years & & & & $\chi_{(1)}^{2}=3,197$ \\
\hline Work Experience * & & $\%$ within Work & $92,3 \%$ & $7,7 \%$ & \\
\hline \multirow[t]{4}{*}{ Q5a. Satış yollarını artırma } & & $\mathrm{N}$ & 111 & 2 & \multirow{3}{*}{$p=0.074$} \\
\hline & $>5$ years & & & & \\
\hline & & $\%$ within Work & $98,2 \%$ & $1,8 \%$ & \\
\hline & & Q5b. & Evet & Hayır & \\
\hline \multirow{3}{*}{ Work Experience * } & & $\mathrm{N}$ & 37 & 2 & \multirow{3}{*}{$\chi_{(1)}^{2}=0,193$} \\
\hline & $0-5$ years & & & & \\
\hline & & $\%$ within Work & $94,9 \%$ & $5,1 \%$ & \\
\hline \multirow{4}{*}{$\begin{array}{l}\text { Q5b. Yenilikçilik ve yeni ürün } \\
\text { geliştirme }\end{array}$} & \multirow{3}{*}{$>5$ years } & $\mathrm{N}$ & 109 & \multirow{2}{*}{4} & \multirow{3}{*}{$p=0.660$} \\
\hline & & & & & \\
\hline & & $\%$ within Work & $96,5 \%$ & $3,5 \%$ & \\
\hline & & Q5c. & Evet & Hayır & \\
\hline \multirow{3}{*}{ Work Experience * } & & $\mathrm{N}$ & 2 & 37 & \multirow{3}{*}{$\chi_{(1)}^{2}=1,276$} \\
\hline & $0-5$ years & & & & \\
\hline & & $\%$ within Work & $5,1 \%$ & $94,9 \%$ & \\
\hline \multirow{3}{*}{$\begin{array}{l}\text { Q5c. Kurumsal kültürü ve } \\
\text { operasyonel işleyişi } \\
\text { geliştirme }\end{array}$} & & $\mathrm{N}$ & 2 & 111 & \multirow{3}{*}{$p=0.259$} \\
\hline & $>5$ years & & & & \\
\hline & & $\%$ within Work & $1,8 \%$ & $98,2 \%$ & \\
\hline
\end{tabular}

The Chi-Square comparisons of the work experience groups are given in Table 7. It is found that there is no statistically significant difference between the work experience groups in any of the questions.

\section{Reference}

Armstrong, Gary and Kotler, Philip (2001), “Marketing: An Introduction”, 5th Edition, Prentice Hall, Inc,

Barnes, S.J (2004), Provision of services via the wireless application protocol, Electronic Markets 
Barutçu, S (2007), “Attitudes towards mobile marketing tools: A Study of Turkish consumers", Journal of Targeting, Measurement and Analysis for Marketing

Bhatti, T (2007), "Exploring factors influencing the adoption of mobile commerce", Journal of Internet Banking and Commerce

Chen, J.V, Ross, W, Huang, S.F (2002), "Privacy, Trust, and Justice Considerations for local Based Mobile Telecommunication Services", The Journal of Policy, regulation and Strategy for Telecommunications, Information, and Media

Chen, L (2008), A model of consumer acceptance of mobile payment, International Journal of Mobile Communications.

Christopher, M (1998), Logistics and Supply Chain Management, Financial Time/Pitman, London,

Cushman\&Wakefield, 2013- 2014 Construction Market Research Analysis

Çalık Gayrimenkul, 2013- 2014 Report

Çavuşgil, T (1985), Service Expectations, Business Horizons

Denk, M, Hackl, M (2004), “Where does mobile business go?”, International Journal of Electronic Business

Etzel, Michael (1997), “Marketing, 11th edition, New York: McGraw-Hill Co.

Gittell, R, Magnusson, M and Merenda, M (2012), The Sustainable Business Case Book

Kassaye, W. Wossen (2001), “Green Dilemma”, Marketing Intelligence\&Planning, USA,

Peppers, D and Rogers, M (2011), Managing Customer Relationships, John Wiley\&Sons Inc, Canada,

PWC Financial Report, 2013

Winer, Russel S (2000),. “Marketing Management”, Prentice Hall Inc

www.iso.org/iso 